\title{
Review
}

\section{Lysophospholipid regulation of mononuclear phagocytes}

\author{
Hsinyu Lee ${ }^{\mathrm{a}, *}$, Jia-Jun Liao ${ }^{\mathrm{a}}$, Markus Graeler ${ }^{\mathrm{b}}$, Mei-Chuan Huang ${ }^{\mathrm{b}}$, Edward J. Goetzl ${ }^{\mathrm{b}}$ \\ ${ }^{a}$ Department of Zoology, National Taiwan University, Taipei, Taiwan, ROC \\ ${ }^{\mathrm{b}}$ Department of Medicine, University of California, San Francisco, CA 94143-0711, USA
}

Received 30 January 2002; accepted 30 January 2002

\begin{abstract}
Blood monocytes and tissue macrophages derived from monocyte differentiation in tissues are central elements of innate immunity in host defense against numerous pathogens and other challenges. These mononuclear phagocytes also participate in wound healing and normal tissue remodeling in development and growth. Pathological perversion of their physiological roles leads to participation of mononuclear phagocytes in fibrosing diseases including granulomatous disorders, chronic inflammation typical of arthritis, and atherosclerosis. Lysophospholipids, including lysophosphatidic acid (LPA) and sphingosine 1-phosphate (S1P), are platelet-derived lipid growth factors considered to participate in leukocyte differentiation and activation. This section summarizes our recent observations of the effects of lysophospholipids on mononuclear phagocytes. (C) 2002 Elsevier Science B.V. All rights reserved.
\end{abstract}

Keywords: Lysophosphatidic acid; Sphingosine 1-phosphate; Macrophage; Wound healing; Atherosclerosis

\section{Development and functions of mononuclear phagocytes}

The development of mature tissue macrophages proceeds through four distinct cell stages, designated monoblasts, promonocytes, monocytes and macrophages, which are defined by their specific cell surface markers and endogenous peroxidatic activity [1,2]. The bone marrow-derived monoblasts and promonocytes are precursors of monocytes. Mature monocytes, which represent about $5 \%$ of white blood cells, are released from bone marrow and are maintained in the circulation for up to 3 days. Those that enter tissue from the vasculature differentiate into macrophages and contribute to a variety of normal processes, such as presentation of antigen to immune cells, phagocytosis and clearing of foreign microorganisms, and tissue remodeling during wound healing $[3,4]$. Tissue macrophages also participate in many pathological conditions, such as atherosclerosis [5], chronic inflammation and cancer [6]. Effects of macrophages are mediated in part by multiple growth factors, which are secreted by activated macrophages [7]. The effects of macrophage-secreted growth factors on

\footnotetext{
* Corresponding author. Tel.: +8862-2363-0231x2352; fax: +88622363-6837.

E-mail address: hsinyulee@yahoo.com (H. Lee).
}

adjacent tissues targets, such as endothelial and smooth muscle cells, and the effects of mediators subsequently secreted by target cells on monocytes and macrophages, are one current focus of atherosclerosis and inflammation research.

\section{Pathological significance of lysophospholipids on wound healing and atherosclerosis}

Lysophosphatidic acid (LPA) and sphingosine 1-phosphate (S1P) are lysophospholipid growth factors, which are generated from multiple cellular sources, of which platelets [8-10], cancer cells [11] and adipose tissues [12] are the most prominent. They bind to $\mathrm{G}$ protein-coupled receptors (GPCRs) of the Edg family, evoking multiple cellular responses, including proliferation and reorganization of cytoskeletal structure (for review, see Ref. [13]). Edg receptors are highly homologous in structure with each other, but differ in ligand specificity and signaling pathways. To date, three LPA-binding receptors and five S1P-binding receptors have been identified in mice, rats and humans.

LPA and S1P have been reported to advance woundhealing processes both in vitro and in vivo [14,15], and the monocyte-macrophage system is essential for this process. Increased vascular levels of oxidized LDL molecules and 
Table 1

Expression patterns of Edg receptors in monocytes and macrophages isolated from different origins

\begin{tabular}{|c|c|c|c|c|c|c|c|c|c|}
\hline & Edg $1 \mathrm{~S}_{1} \mathrm{P}_{1}$ & Edg $2 \mathrm{LPA}_{1}$ & Edg $3 \mathrm{~S} \mathrm{P}_{3}$ & Edg $4 \mathrm{LPA}_{2}$ & Edg $5 \mathrm{~S}_{1} \mathrm{P}_{2}$ & Edg $6 \mathrm{~S}_{1} \mathrm{P}_{4}$ & Edg $7 \mathrm{LPA}_{3}$ & Edg $8 \mathrm{~S} 1 \mathrm{P}_{5}$ & \\
\hline Human peripheral monocyte & & + & + & & + & N.D. & N.D. & N.D. & this report \\
\hline Mouse peritoneal macrophage & + & + & & & + & & & & this report \\
\hline Rat alveolar macrophage & & + & & & + & + & & & Ref. [27] \\
\hline Human alveolar macrophage & + & + & & + & & & + & & Ref. [27] \\
\hline J774 Mouse macrophage & + & + & & & + & + & N.D. & N.D. & this report \\
\hline
\end{tabular}

Note: N.D. $=$ not determined.

LPA have been observed to coincide with the development of atherosclerotic lesions [16-18]. Furthermore, abnormal interactions between monocytes and endothelial cells have been suggested to be one of the early events in the accumulation of oxidized LDL and LPA, and the generation of the atherosclerotic plaque $[19,20]$. LPA and S1P are capable of modulating the expression patterns of vascular adhesion molecules, including ELAM and VECAM, by endothelial cells [21-23]. The expression of these adhesion molecules is essential for the recruitment of circulating platelets and leukocytes to the endotheliumin atherosclerosis, as well as during inflammation and immune responses. Several groups had reported the effects of LPA and S1P on leukocyte interactions with the endothelium. In one study, S1P inhibited neutrophil-endothelial cell interaction and subsequent neutrophil invasion [24], while in another report [23], LPA enhanced HL60 cell adherence to human aortic endothelial cells. Apparent diversity of LPA and S1P effects may be attributed to the use of different leukocytes and endothelial cell types. These observations suggest that the effects of LPLs on the monocyte-macrophage system might be important during wound healing and formation of atherosclerosis. However, only few reports have been published describing the effects of LPA and S1P on the monocytemacrophage system [25-27].

\section{Edg receptors expressed on mononuclear phagocytes}

In our laboratory, we are interested in investigating the roles of LPA and S1P in cells of the mononuclear leukocyte lineage. By traditional RT-PCR and fluorometric-based kinetic RT-PCR, we identified the expression profiles of Edg receptors in freshly isolated human monocytes and mouse peritoneal macrophages. Human blood monocytes express Edg 2, 3, and 5 but not 1 or 4. Mouse macrophages

Table 2

LPA and S1P effects on cytokine gene expression by mouse peritoneal macrophage

\begin{tabular}{lllll}
\hline & Interleukin-1 $\beta$ & Interleukin-2 & TNF $\alpha$ & GAPDH \\
\hline Control & + & +++ & + & +++ \\
LPA & ++ & + & +++ & +++ \\
S1P & +++ & + & +++ & +++ \\
\hline
\end{tabular}

Note: $+=$ weak signals; $++=$ intermediate signals; $+++=$ strong signals. express Edg 1, 2 and 5 but not 3, 4, 6, 7 or 8. J774A.1 cell, a mouse macrophage cell line frequently used in related studies, also expressed Edg receptors as detected by RT-PCR. In a recent publication, Hornuß et. al. [27] showed that Edg receptors are expressed in rat and human alveolar macrophages, but the expression was in a distinct pattern (Table 1). These results suggest that receptors for both LPA and S1P are expressed on monocytes and macrophages, which are distinct
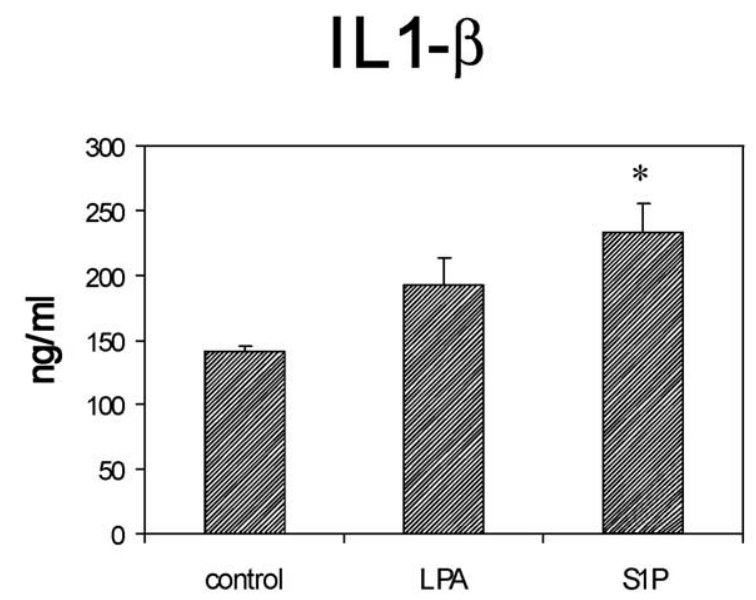

$\mathrm{TNF} \alpha$

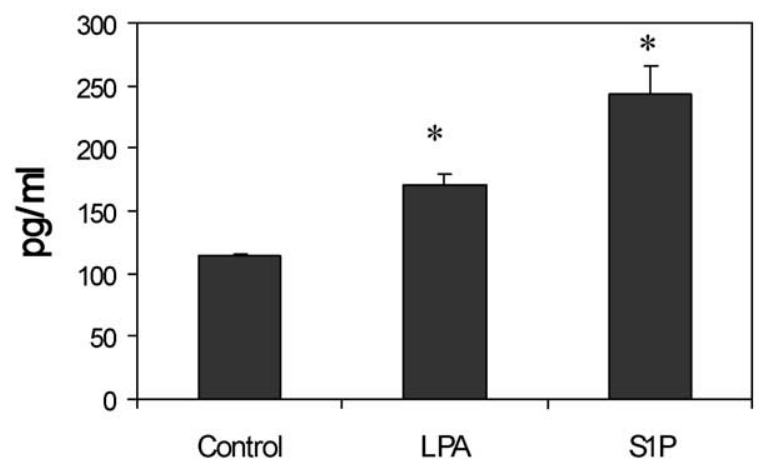

Fig. 1. Enhancement of IL-1 $\beta$ and TNF $\alpha$ secretion from mouse peritoneal macrophages by LPA and S1P. Conditioned media from control or $10 \mu \mathrm{M}$ LPA- or S1P-treated mouse peritoneal macrophages were analyzed by ELISA recognizing mouse IL-1 $\beta$ (upper panel) and TNF $\alpha$ (lower panel). Data are presented as mean \pm S.E. and analyzed by one-way ANOVA followed by Fisher's protected least-significant differences test $(n=4$; $* P<0.05)$. 
Con

LPA S1P

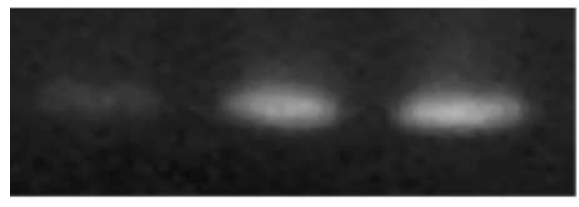

IL1 $\beta$

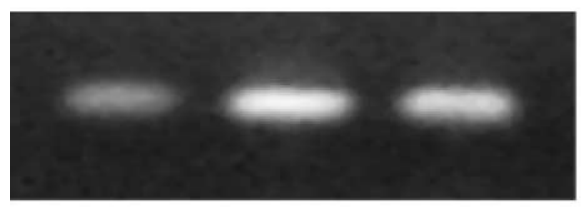

$\mathrm{TNF} \alpha$

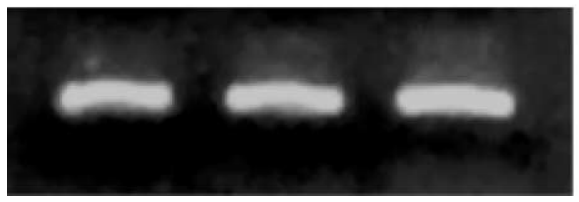

GAPDH

Fig. 2. Effects of LPA and S1P on IL-1 $\beta$ and TNF $\alpha$ mRNA levels in J774A. 1 mouse macrophages. mRNA isolated from control or $1 \mu \mathrm{M}$ LPAor S1P-treated J774A.1 cells were analyzed by RT-PCR using primer-sets specific for IL-1 $\beta$ (upper lanes), TNF $\alpha$ (middle lanes) and GAPDH (lower lanes).

from profiles of expression of Edg receptors by $\mathrm{T}$ and $\mathrm{B}$ lymphocyte [28,29].

\section{Macrophage-genes regulated by LPA and S1P}

Since receptors for LPA and S1P are expressed on monocytes and macrophages, we examined LPA- and S1P-induced gene modulation in macrophages by DNA array technology. As indicated in Table 2, we found that IL-1 $\beta$ and TNF- $\alpha$ genetic messages are both up-regulated, whereas IL-2 message expression was inhibited by LPA and S1P in freshly isolated mouse peritoneal macrophages. We further confirmed our observations by determining the levels of secreted IL-1 $\beta$ and TNF- $\alpha$ in LPL-treated macrophage conditioned media by ELISA (Fig. 1). J774A.1 mouse macrophages also responded to LPLs with enhancement of both IL-1 $\beta$ and TNF- $\alpha$ mRNA expression as detected by RT-PCR (Fig. 2). Both IL-1 $\beta$ and TNF- $\alpha$ are cytokines that regulate blood vessel environment and, specifically, endothelial cell physiology. IL-1 $\beta$ and TNF- $\alpha$ also participate in a self-augmentation induction mechanism [30], which allows a positive feedback mechanism to amplify the effects of these cytokines within a local milieu. Furthermore, TNF- $\alpha$ directly and potently stimulates sphingosine kinase activity in HUVEC, which induces the generation of S1P that further enhances endothelial and macrophage functions [21]. These results suggest that LPA and S1P are important regulators of interactions between endothelial cells and mononuclear phago- cytes, and might play an important role in regulation of wound healing and generation of atherosclerosis.

\section{References}

[1] M. Rutherford, A. Witsell, L. Schook, J. Leukocyte Biol. 53 (1993) $602-618$.

[2] R.H.J. Beelen, M.G.H. Betjes, E.W.A. Kamperdijk, Macrophage: General Aspects, Academic Press, London, 1994.

[3] C.F. Nathan, H.W. Murray, Z.A. Cohn, N. Engl. J. Med. 303 (1980) $622-626$.

[4] M.J. Auger, J.A. Ross, in: C.E. Lewis, J.O.D. McGee (Eds.), The Macrophage, Oxford Univ. Press, Oxford, UK, 1993, pp. 1-74.

[5] M.E. Rosenfeld, R. Ross, Arteriosclerosis 10 (1990) 680-687.

[6] C. Sunderkotter, K. Steinbrink, M. Goebeler, R. Bhardwaj, C. Sorg, J. Leukocyte Biol. 55 (1994) 410-422.

[7] A.A. te Velde, in: C.A.F.M. Bruijnzeel-Koomen, E.C.M Hoefsmit (Eds.), Immunopharmacology of Macrophages and Other AntigenPresenting Cells, Academic Press, London, 1994, pp. 7-34.

[8] W.H. Moolenaar, J. Biol. Chem. 270 (1995) 12949-12952.

[9] S. Spiegel, O. Cuvillier, L.C. Edsall, T. Kohama, R. Menzeleev, Z. Olah, A. Olivera, G. Pirianov, D.M. Thomas, Z. Tu, J.R. Van Brocklyn, F. Wang, Ann. N. Y. Acad. Sci. 845 (1998) 11-18.

[10] T. Eichholtz, K. Jalink, I. Fahrenfort, W.H. Moolenaar, Biochem. J. 291 (1993) 677-680.

[11] Z. Shen, J. Belinson, R.E. Morton, Y. Xu, Gynecol. Oncol. 71 (1998) $364-368$.

[12] C. Pages, P. Valet, O. Jeanneton, A. Zakaroff-Girard, P. Barbe, M. Record, C. Wolf, F. Chevy, M. Lafontan, J.S. Saulnier-Blache, Lipids 34 (1999) S79, Suppl.

[13] E.J. Goetzl, S. An, FASEB J. 12 (1998) 1589-1598.

[14] H. Lee, E.J. Goetzl, S. An, Am. J. Physiol.: Cell Physiol. 278 (2000) C612-C618.

[15] L. Balazs, J. Okolicany, M. Ferrebee, B. Tolley, G. Tigyi, Am. J. Physiol.: Regul., Integr. Comp. Physiol. 280 (2001) R466-R472.

[16] W. Siess, K. Zangl, M. Essler, M. Bauer, R. Brandl, C. Corrinth, R. Bittman, G. Tigyi, M. Aepfelbacher, Proc. Natl. Acad. Sci. U. S. A. 96 (1999) 6931-6936.

[17] M. Essler, M. Retzer, M. Bauer, K. Zangl, G. Tigyi, W. Siess, Ann. N. Y. Acad. Sci. 905 (2000) 282-286.

[18] P. Maschberger, M. Bauer, J. Baumann-Siemons, K.J. Zangl, E.V. Negrescu, A.J. Reininger, W. Siess, J. Biol. Chem. 275 (2000) 1915919166.

[19] R.G. Garrity, Am. J. Pathol. 103 (1981) 181-199.

[20] R. Ross, N. Engl. J. Med. 340 (1999) 115-126.

[21] P. Xia, J. Gamble, K. Rye, L. Wang, C. Hii, P. Cockerill, Y. KhewGoodall, A. Bert, P. Barter, M. Vadas, Proc. Natl. Acad. Sci. U. S. A. 95 ( 1998) 14196-14201.

[22] M.J. Lee, S. Thangada, K.P. Claffey, N. Ancellin, C.H. Liu, M. Kluk, M. Volpi, R.I. Sha'afi, T. Hla, Cell 99 (1999) 301-312.

[23] C. Rizza, N. Leitinger, J. Yue, D. Fischer, D. Wang, P. Shih, H. Lee, G. Tigyi, J. Berliner, Lab. Invest. 79 (1999) 1227-1235.

[24] S. Kawa, S. Kimura, S. Hakomori, Y. Igarashi, FEBS Lett. 420 (1997) $196-200$

[25] D. Zhou, W. Luini, S. Bernasconi, L. Diomede, M. Salomona, A. Mantovani, S. Sozzani, J. Biol. Chem. 270 (1995) 25549-25556.

[26] J. Koh, W. Lieberthal, S. Heydrick, J. Levine, J. Clin. Invest. 102 (1998) 716-727.

[27] C. Hornuß, R. Hammermann, M. Fuhrmann, U.R. Juergens, K. Racke, Eur. J. Pharmacol. 429 (2001) 303-308.

[28] E.J. Goetzl, Y. Kong, J.K. Voice, J. Immunol. 164 (2000) 4996-4999.

[29] Y. Zheng, J.K. Voice, Y. Kong, E.J. Goetzl, FASEB J. 14 (2000) 2387-2389.

[30] C. Dinarello, Adv. Immunol. 44 (1989) 153-205. 